\title{
Pembelajaran Matematika Berbasis Masalah untuk Meningkatkan Kemampuan Penalaran Matematika dan Motivasi Belajar Siswa Kelas IV SD
}

\author{
Kasturi $^{1}$, Ma'rufi $^{2}$, Nurdin $^{2}$ \\ Universitas Cokroaminoto Palopo ${ }^{1,2}$ \\ Universitas Muhammadiyah Enrekang ${ }^{3}$ \\ Email: kasturituri691@gmail.com¹, marufi@uncp.ac.id², enambelasnurdin@gmail.com³,
}

\begin{abstract}
Abstrak. Penelitian ini bertujuan untuk mengetahui apakah terdapat peningkatan kemampuan penalaran matematika dan motivasi belajar siswa kelas IV SD Negeri 239 Salu Minanga kecamatan Malili setelah penerapan model pembelajaran matematika berbasis masalah. Penelitian ini merupakan penelitian kuantitatif dengan pendekatan eksperimen semu. Penelitian ini dilaksanakan di SD Negeri 239 Salu Minanga Kecamatan Malili pada tanggal $24 \mathrm{Mei}-18$ juni 2021 . Satuan eskperimen yaitu siswa kelas IV SD Negeri 239 Salu Minanga Kecamatan Malili sewbanyak 36 siswa. Perlakuan yang diberikan adalah pembelajaran matematika berbasis masalah. Instrumen penelitian ini adalah tes penalaran matematika, dan angket motivasi belajar. Data yang diperoleh pada penelitian ini dianalisis secara deskritif dan inferensial. Hasil penelitian ini yaitu 1) terdapat peningkatan kemampuan penalaran matematika siswa kelas IV SD Negeri 239 Salu Minanga kecamatan Malili setelah penerapan pembelajaran matematika berbasis masalah. 2) terdapat peningkatan motivasi belajar siswa kelas IV SD Negeri 239 Salu Minanga kecamatan Malili setelah penerapan pembelajaran matematika berbasis masalah.
\end{abstract}

\section{Kata Kunci: Kemampuan penalaran matematika, motivasi belajar, pembelajaran berbasis masalah}

\begin{abstract}
This study aims to determine whether there is an increase in mathematical reasoning ability and learning motivation of fourth grade students of SD Negeri 239 Salu Minanga, Malili sub-district after the application of the problem-based mathematics learning model. This research is a quantitative research with a quasi-experimental approach. This research was conducted at SD Negeri 239 Salu Minanga, Malili District, on 24 May - 18 June 2021. The experimental unit is the fourth grade students of SD Negeri 239 Salu Minanga, Malili District, with a total of 36 students. The treatment given is problem-based mathematics learning. The research instrument is a test of mathematical reasoning, and a learning motivation questionnaire. The data obtained in this study were analyzed descriptively and inferentially. The results of this study are 1) there is an increase in the mathematical reasoning ability of fourth grade students of SD Negeri 239 Salu Minanga, Malili sub-district after the application of problem-based mathematics learning. 2) there is an increase in the learning motivation of fourth grade students at SD Negeri 239 Salu Minanga, Malili sub-district after the application of problem-based mathematics learning.
\end{abstract}

Keywords: Mathematical reasoning ability, learning motivation, problem-based learning

\section{A. Pendahuluan}

Belajar matematika penting dilakukan, hal ini tidak terlepas dari peran matematika dalam berbagai aspek kehidupan. Matematika dapat berperan sebagai alat pikir, alat berkomunikasi, alat untuk memecahkan berbagai persoalan praktis, yang unsur-unsurnya logika dan intuisi (Uno dalam Ma'rufi, Pasandaran, \& Yogi 2018). Menurut depdiknas (2006) pembelajaran matematika yang dilakukan diharakan dapat melatih cara berpikir dan bernalar dalam menarik kesimpulan, mengembangkan kemampuan memecahkan masalah, serta mengembangkan kemampuan menyampaikan informasi atau mengkomunikasikan ide-ide melalui lisan, tulisan, gambar, grafik, peta, diagram, dan sebagainya. Sehingga setelah mempelajari matematika diharapkan terbiasa berpikir secara sistematis, ilmiah, menggunakan logika, bernalar, kritis, serta kreatif. 
Tingginya tuntutan untuk menguasai matematika tidak berbanding lurus dengan kemampuan matematika siswa utamanya pada siswa sekolah dasar. Terlihat dari hasil study TIMSS (Trends in International Mathematic and Science Study) yang diikuti siswa kelas IV sekolah dasar tahun 2015, hasil tes menunjukkan prestasi matematika siswa di Indonesia berada pada peringkat 44 dari 49 negara pengikut dengan skor sebesar 397 jauh lebih rendah dibanding rataan skor international yaitu 500 (Mullis, Martin, Foi, \& Hooper, 2016). Berdasarkan hasil study TIMSS ini, salah satu aspek kemampuan matematika yang menjadi titik lemah siswa indonesia siswa kurang memahami dan menggunakan nalar yang baik dalam menyelesaikan soal yang diberikan. Sejalan dengan itu, hasil wawancara dengan salah satu guru matematika di SD Negeri 239 Salu Minanga Kecamatan Malili yaitu siswa dapat mengerjakan soal matematika apabila soal yang diberikan sesuai dengan contoh yang ada, namun apabila soal yang diberikan berbeda sedikit dari contoh yang ada,siswa akan mengalami kesulitan dalam mengerjakannya. Ini menunjukkan kemampuan penalaran siswa masih rendah

Rendahnya kemampuan penalaran siswa di indonesia karena pembelajaran matematika pada sekolah dasar masih berpusat guru, siswa hanya dilatih menyelesaikan masalah secara prosedural tanpa pemahaman yang mendalam, sehigga siswa kurang menguasai konsep yang diberikan.hal ini senada dengan hasil survey IMSTEP-JICA (Casnan, Mahpudin, \& Fuadi, 2017) menjelaskan bahwa pembelajaran matematika yang di lakukan guru disekolah terlalu berkonsentrasi pada hal-hal yang prosedural dan mekanistik, pembelajaran berpusat pada guru, konsep matematika disampaikan secara informatif, dan siswa dilatih menyelesaikan banyak soal tanpa pemahaman yang mendalam. Sehingga kemampuan matematika seperti kemampuan penalaran tidak berkembang.

Meningkatkan kemampuan penalaran matematika penting dilakukan, karena penalaran memiliki peran yang sangat penting dalam proses berpikir siswa karena jika kemampuan bernalar siswa tidak dikembangkan maka pembelajaran matematika hanya akan menjadi materi yang mengikuti serangkaian prosedur dan meniru contoh-contoh tanpa mengetahui maknanya (Usniati, 2011). Selain kemampuan penalaran matematika yang rendah, pembelajaran matematika yang berpusat kepada guru menyebabkan motivasi belajar siswa juga rendah, hal ini dikarenakan pembelajaran yang dilakukan kurang menarik/mendorong siswa untuk aktif dalam pembelajaran, selain itu, siswa cenderung mengangap matematika pelajaran yang sulit yang menyebabkan siswa malas untuk belajar matematika.

Berdasarkan hal tersebut, perlu upaya untuk meningkatkan kemampuan penalaran matematika dan motivasi belajar siswa, Proses pembelajaran matematika yang dilakukan perlu lebih kreatif dan inovatif agar dapat meningkatkan kemampuan penalaran matematika dan motivasi belajar siswa. salah satu upaya yang dilakukan yaitu dengan menerapkan model pembelajaran berbasis masalah.

Model pembelajaran berbasis masalah adalah model pembelajaran yang pembelajarannya menggunakan sebuah masalah nyata dan siswa di bimbing dalam menyelesaikan masalah tersebut, sehingga konsep yang diajarkan dapat dipahami secara mendalam oleh siswa. Duch (Sumartini, 2015) mendefinisikan bahwa pembelajaran berbasis masalah merupakan pendekatan pembelajaran yang mempunyai ciri menggunakan masalah nyata sebagai konteks bagi siswa untuk belajar berpikir kritis, keterampilan pemecahan masalah, dan memperoleh pengetahuan.. Sejalan dengan itu, Arends (2008) pembelajaran berbasis masalah dirancang terutama untuk membantu siswa mengembangkan keterampilan berpikir, keterampilan menyelesaikan masalah, dan keterampilan intelektualnya. Menerapkan pembelajaran berbasis masalah dalam pembelajaran, akan melatih siswa untuk berpikir dan bernalar mencari, menemukan,menyelesaikan dan menyimpulkan solusi dari masalah yang diberikan sehingga diharapkan kemampuan penalaran matematika siswa dapat meningkat. Selain itu menerapkan pembelajaran berbasis masalah dalam pembelajaran di harapkan siswa menjadi aktif dalam 
pembelajaran sehingga motivasi siswa dalam belajar dapat meningkat utamanya belajar matematika.

Berdasarkan uraian diatas, tujuan penelitian ini adalah untuk mengetahui apakah pembelajaran matematika berbasis masalah dapat meningkatkan kemampuan penalaran matematika dan motivasi belajar siswa kelas IV SD Negeri 239 Salu Minanga Kecamatan Malili

\section{B. Metodologi Penelitian}

Penelitian ini merupakan penelitian kuantitatif dengan pendekatan eksperimen semu. Penelitian ini dilaksanakan di SD Negeri 239 Salu Minanga Kecamatan Malili pada tanggal 24 Mei - 18 juni 2021. Satuan eskperimen yaitu siswa kelas IV SD Negeri 239 Salu Minanga Kecamatan Malili sebanyak 36 siswa. Perlakuan yang diberikan adalah pembelajaran matematika berbasis masalah.

Langkah-langkah penerapan model pembelajaran berbasis masalah sebagai berikut.

Tabel 1. Tahapan-tahapan pembelajaran berbasis masalah

\begin{tabular}{|c|c|}
\hline Tahapan & Kegiatan Guru \\
\hline $\begin{array}{l}\text { Tahap 1 Orientasi siswa kepada } \\
\text { masalah }\end{array}$ & $\begin{array}{l}\text { Guru menjelaskan tujuan pembelajaran, menjelaskan logistik } \\
\text { yang dibutuhkan, memotivasi siswa agar terlibat pada aktivitas } \\
\text { pemecahan masalah yang dipilihnya }\end{array}$ \\
\hline $\begin{array}{c}\text { Tahap } 2 \text { Mengorganisasi siswa } \\
\text { untuk belajar }\end{array}$ & $\begin{array}{l}\text { Guru membantu siswa mer } \\
\text { tugas belajar yang berhubui }\end{array}$ \\
\hline $\begin{array}{l}\text { Tahap } 3 \text { Membimbing } \\
\text { penyelidikan individual } \\
\text { dan kelompok }\end{array}$ & $\begin{array}{l}\text { Guru mendorong siswa untuk mengumpulkan informasi yang } \\
\text { sesuai, melaksankan eksperimen, untuk mendapatkan } \\
\text { penjelasan dan pemecahan masalah }\end{array}$ \\
\hline $\begin{array}{c}\text { Tahap } 4 \text { Mengembangkan dan } \\
\text { menyajikan hasil karya }\end{array}$ & $\begin{array}{l}\text { Guru membantu siswa merencanakan dan menyiapkan karya } \\
\text { yang sesuai seperti laporan, video, dan model serta membantu } \\
\text { mereka berbagi tugas dengan temannya }\end{array}$ \\
\hline $\begin{array}{c}\text { Tahap } 5 \text { Menganalisis dan } \\
\text { mengevaluasi proses } \\
\text { pemecahan masalah }\end{array}$ & $\begin{array}{l}\text { Guru membantu melakukan refleksi atau evaluasi terhadap } \\
\text { penyelidikan dan proses-proses yang mereka gunakan. }\end{array}$ \\
\hline
\end{tabular}

Sumber: Sofyan, \& Komariah, (2016)

Instrumen penelitian ini adalah tes penalaran matematika, dan angket motivasi belajar. Data yang diperoleh pada penelitian ini dianalisis secara deskritif dan inferensial. Analisis secara deskriptif dilakukan untuk melihat gambaran secara deskriptif kemampuan penalaran matematika dan motivasi belajar siswa sebelum dan setelah di ajar pembelajaran matematika berbasi masalah. Analisis secara inferesial dilakukan untuk menguji hipotesis. Terdapat 2 hipotesis dalam penelitian ini yaitu:

1. Terdapat peningkatan kemampuan penalaran matematika siswa kelas IV SD Negeri 239

Salu Minanga kecamatan Malili setelah penerapan model pembelajaran matematika berbasis masalah.

2. Terdapat peningkatan motivasi belajar siswa kelas IV SD Negeri 239 Salu Minanga kecamatan Malili setelah penerapan model pembelajaran matematika berbasis masalah.

Hipotesis 1 di uji dengan menggunakan uji one sample t test dan hipotesis 2 diuji dengan menggunakan uji paired sample t test. Dengan uji prasyarat yaitu uji normalitas 


\section{Hasil Penelitian dan Pembahasan}

1. Kemampuan Penalaran Matematika

Berdasarkan hasil analisis, rangkuman statistika deskriptif kemampuan penalaran matematika siswa kelas IV SD negeri 239 Salu Minanga kecamatan Malili sebelum dan setelah diajar dengan pembelajaran matematika berbasis masalah sebagai berikut.

Tabel 2. Statistik deskriptif kemampuan penalaran matematika siswa

\begin{tabular}{lrr}
\hline Statistik & Nilai statistik Pretest & Nilai statistik Posttest \\
\hline Ukuran sampel & 36 & 36 \\
Rata-rata & 50,92 & 79,81 \\
Nilai tertinggi & 66,67 & 93,33 \\
Nilai terendah & 33,34 & 60 \\
Nilai maksimun & 100 & 100 \\
Standar deviasi & 8,30 & 7,56 \\
Variansi & 68,95 & 57,11 \\
Rentang & 33,34 & 33,33 \\
\hline
\end{tabular}

Sumber: Data primer setelah di olah (2021)

Tabel 2 menunjukkan kemampuan penalaran matematika siswa kelas IV SD negeri 239 Salu Minanga kecamatan Malili sebelum diajar dengan pembelajaran matematika berbasis masalah, dari 36 siswa, miliki nilai rata-rata 50,92, nilai tertinggi 66,67, nilai terendah 33,34 dari nilai maksimun yang dapat diperoleh siswa 100. Sedangkan kemampuan penalaran matematika siswa kelas IV SD negeri 239 Salu Minanga kecamatan Malili setelah diajar dengan pembelajaran matematika berbasis masalah, dari 36 siswa miliki nilai rata-rata 79,81, nilai tertinggi 93,33, nilai terendah 60 dari nilai maksimun yang dapat diperoleh siswa 100.

Selanjutnya, distribusi frekuensi kemampuan penalaran matematika siswa kelas IV SD negeri 239 Salu Minanga kecamatan Malili sebelum dan setelah diajar dengan pembelajaran matematika berbasis masalah sebagai berikut.

Tabel 3. Distribusi frekuensi kemampuan penalajaran matematika siswa

\begin{tabular}{crrrrr}
\hline \multirow{2}{*}{ Interval } & \multicolumn{2}{c}{ pretest } & \multicolumn{2}{c}{ posttest } & \multirow{2}{*}{ Kategori } \\
\cline { 2 - 5 } & \multicolumn{1}{c}{ Frekuensi } & $\mathbf{( \% )}$ & Frekuensi & \multicolumn{1}{|}{$(\mathbf{\%})$} & \\
\hline $90 \leq x \leq 100$ & 0 & 0 & 2 & 5,55 & Sangat Tinggi \\
$80 \leq x<90$ & 0 & 0 & 24 & 66,67 & Tinggi \\
$65 \leq x<80$ & 2 & 5,56 & 9 & 25,00 & Sedang \\
$55 \leq x<65$ & 25 & 69,44 & 1 & 2,78 & Rendah \\
$0 \leq x<55$ & 9 & 25,00 & 0 & 0 & Sangat Rendah \\
\hline Jumlah & $\mathbf{3 6}$ & $\mathbf{1 0 0}$ & $\mathbf{3 6}$ & $\mathbf{1 0 0}$ & \\
\hline Rata-rata & $\mathbf{5 0 , 9 2}$ & Rendah & $\mathbf{7 9 , 8 1}$ & Sedang & \\
\hline
\end{tabular}

Sumber: Data primer setelah di olah (2021)

Tabel 3 menunjukkan kemampuan penalaran matematika siswa sebelum diajar kembelajaran matematika berbasis masalah yaitu dari 36 siswa, terdapat 2 siswa yang memiliki kemampuan penalaran matematika sedang, 25 siswa yang memiliki kemampuan penalaran matematika rendah, dan 9 siswa yang memiliki kemampuan penalaran sangat rendah. Rata-rata kemampuan penalaran matematika siswa sebelum diajar pembelajaran matematika berbasis masalah berada pada kategori rendah. Kemampuan penalaran matematika siswa setelah diajar dengan pembelajaran matematika berbasis masalah yaitu dari 36 siswa terdapat 2 siswa yang memiliki kemampuan penalaran matematika sangat tinggi, 24 siswa yang memiliki kemampuan penalaran matematika tinggi, 9 siswa yang memiliki kemampuan penalaran sedang dan 1 siswa 
yang memiliki kemampuan penalaran rendah. Rata-rata kemampuan penalaran siswa setelah diajar dengan pembelajaran matematika berbasi masalah berada pada kategori sedang. Ini menunjukkan setelah diajar dengan pembelajaran matematika berbasis masalah, kemampuan penalaran matematika siswa kelas IV SD negeri Salu Minanga kecamatan Malili mengalami peningkatan.

Peningkatan kemampuan penalaran matematika siswa kelas IV SD negeri Salu Minanga kecamatan Malili setelah diajar dengan pembelajaran matematika berbasis masalah dapat dilihat pada tabel gain kemampuan penalaran matematika siswa sebagai berikut.

Tabel 4. Gain kemampuan penalaran matematika siswa

\begin{tabular}{ccrrr}
\hline No & Koefisien & Frekuensi & Persentase $(\%)$ & \multicolumn{2}{c}{ Klasifikasi } \\
\hline 1 & $g<0,3$ & 1 & 2,78 & Rendah \\
2 & $0,3 \leq g<0,7$ & 26 & 72,22 & Sedang \\
3 & $g \geq 0,7$ & 9 & 25,00 & Tinggi \\
\hline Jumlah & & $\mathbf{3 6}$ & $\mathbf{1 0 0}$ & \\
\hline Rata-rata & & $\mathbf{0 , 5 8}$ & & \multicolumn{2}{c}{ Sedang } \\
\hline
\end{tabular}

Sumber: Data primer setelah di olah (2021)

Tabel 4 menunjukkan rata-rata gain kemampuan penalaran siswa berada pada kategori sedang, artinya peningkatan kemampuan penalaran siswa kelas IV SD negeri Salu Minanga setelah diajar dengan pembelajaran matematika berbasis masalah tergolong sedang. Dari tabel terlihat juga, dari 34 siswa, terdapat 1 siswa yang menagalami peningkatan kemampuan penalaran matematika rendah, 26 siswa yang menagalami peningkatan kemampuan penalaran sedang, dan 9 siswa yang mengalami peningkatan kemampuan penalaran tinggi.

\section{Motivasi belajar siswa}

Berdasarkan hasil analisis, rangkuman statistika deskriptif motivasi belajar matematika siswa kelas IV SD negeri 239 Salu Minanga kecamatan Malili sebelum dan setelah diajar dengan pembelajaran matematika berbasis masalah sebagai berikut.

Tabel 5. Statistik deskriptif motivasi belajar siswa

\begin{tabular}{lrr}
\hline Statistik & Nilai statistik Pretest & Nilai statistik Posttest \\
\hline Ukuran sampel & 36 & 36 \\
Rata-rata & 80,42 & 100,94 \\
Nilai tertinggi & 98 & 113 \\
Nilai terendah & 69 & 94 \\
Nilai maksimun & 120 & 120 \\
Standar deviasi & 7,79 & 4,93 \\
Variansi & 60,65 & 24,34 \\
Rentang & 29,00 & 19,00 \\
\hline
\end{tabular}

Sumber: Data primer setelah di olah (2021)

Tabel 5 menunjukkan motivasi belajar matematika siswa kelas IV SD negeri 239 Salu Minanga kecamatan Malili sebelum diajar dengan pembelajaran matematika berbasis masalah, dari 36 siswa, miliki nilai rata-rata 80,42, nilai tertinggi 98, nilai terendah 69 dari nilai maksimun yang dapat diperoleh siswa 120. Sedangkan motivasi belajar matematika siswa kelas IV SD negeri 239 Salu Minanga kecamatan Malili setelah diajar dengan pembelajaran matematika berbasis masalah, dari 36 siswa miliki nilai rata-rata 100,94, nilai tertinggi 113 nilai terendah 94 dari nilai maksimun yang dapat diperoleh siswa 120 . 
Selanjutnya, distribusi frekuensi motivasi belajar matematika siswa kelas IV SD negeri 239 Salu Minanga kecamatan Malili sebelum dan setelah diajar dengan pembelajaran matematika berbasis masalah sebagai berikut.

Tabel 6. Distribusi frekuensi motivasi belajar matematika siswa

\begin{tabular}{crrrrr}
\hline \multirow{2}{*}{ Interval } & \multicolumn{2}{c}{ pretest } & \multicolumn{2}{c}{ posttest } & \multirow{2}{*}{ Kategori } \\
\cline { 2 - 5 } & \multicolumn{1}{c}{ Frekuensi } & $\mathbf{( \% )}$ & Frekuensi & $\mathbf{( \% )}$ & \\
\hline $\mathrm{x} \geq 97,5$ & 1 & 2,78 & 26 & 72,22 & Sangat Tinggi \\
$82,5 \leq \mathrm{x}<97,5$ & 12 & 33,33 & 10 & 27,78 & Tinggi \\
$67,5 \leq \mathrm{x}<82,5$ & 23 & 63,89 & 0 & 0,00 & Sedang \\
$52,5 \leq \mathrm{x}<67,5$ & 0 & 0,00 & 0 & 0,00 & Rendah \\
$\mathrm{x}<52,5$ & 0 & 0,00 & 0 & 0,00 & Sangat Rendah \\
\hline Jumlah & $\mathbf{3 6}$ & $\mathbf{1 0 0}$ & $\mathbf{3 6}$ & $\mathbf{1 0 0}$ & \\
\hline Rata-rata & $\mathbf{8 0 , 4 2}$ & Sedang & $\mathbf{1 0 0 , 8 9}$ & Sangat Tinggi & \\
\hline
\end{tabular}

Sumber: Data primer setelah di olah (2021)

Tabel 6 menunjukkan motivasi belajar matematika siswa sebelum diajar pembelajaran matematika berbasis masalah yaitu dari 36 siswa, terdapat 1 siswa yang memiliki botivasi belajar sangat tinggi. 12 siswa yang memiliki motivasi belajar tinggi, dan 23 siswa yang memiliki motivasi belajar sedang. Rata-rata motivasi belajar matematika siswa sebelum diajar pembelajaran matematika berbasis masalah berada pada kategori sedang. Motivasi belajar matematika siswa setelah diajar dengan pembelajaran matematika berbasis masalah yaitu dari 36 siswa terdapat 26 siswa yang memiliki motivasi belajar sangat tinggi, dan 10 siswa yang memiliki motivasi belajar tinggi. Rata-rata motivasi belajar siswa setelah diajar dengan pembelajaran matematika berbasi masalah berada pada kategori sangat tinggi. Ini menunjukkan setelah diajar dengan pembelajaran matematika berbasis masalah, motivasi belajar matematika siswa kelas IV SD negeri Salu Minanga kecamatan Malili mengalami peningkatan.

\section{E. Hasil uji hipotesis}

Uji ini dilakukan untuk menjawab hipotesis yang telah di rumuskan, terdapat 2 hipotesis dalam penelitian ini. Hipotesis 1 diuji dengan menggunakan one sample $t$ test dan hipotesis 2 diuji dengan menggunakan paired sample t test. Namun sebelum dilakukan uji hipotesis terlebih dahulu dilakukan uji normalitas. Hasil uji normalitas sebagai berikut.

Tabel 7. Uji normalitas

\begin{tabular}{lcl}
\hline \multicolumn{1}{c}{ Variabel } & Nilai Probabilitas & Kategori \\
\hline Gain kemampuan penalaran matematika & $0,200^{*}$ & Berdistribusi Normal \\
pretest motivasi belajar & 0,146 & Berdistribusi Normal \\
posttest motivasi belajar & $0,200^{*}$ & Berdistribusi Normal \\
\hline
\end{tabular}

Sumber: Data primer setelah di olah (2021)

Tabel 7 menunjukkan bahwa nlai probabilitas semua variabel $>0,05$. Artinya gain kemampuan penaralan matematika, pretest motivasi belajar dan posttest motivasi belajar berada pada distribusi normal.

Hasil uji hipotesis 1 sebagai berikut 


\begin{tabular}{|c|c|c|c|c|c|c|}
\hline \multicolumn{7}{|c|}{ One-Sample T-test } \\
\hline & \multicolumn{6}{|c|}{ Test Value $=0.29$} \\
\hline & \multirow[t]{2}{*}{$\mathrm{t}$} & \multirow[t]{2}{*}{ df } & \multirow{2}{*}{$\begin{array}{l}\text { Sig. (2- } \\
\text { tailed) }\end{array}$} & \multirow{2}{*}{$\begin{array}{c}\text { Mean } \\
\text { Differenc } \\
\mathrm{e}\end{array}$} & \multicolumn{2}{|c|}{$\begin{array}{l}\text { 95\% Confidence Interval of the } \\
\text { Difference }\end{array}$} \\
\hline & & & & & Lower & Upper \\
\hline $\begin{array}{lr}\text { Gain } & \text { Kemampuan } \\
\text { Penalaran Matematika }\end{array}$ & 11,733 & 35 & 0,000 & 0,29366 & 0,2428 & 0,3445 \\
\hline
\end{tabular}

Sumber: Data primer setelah di olah (2021)

Tabel 8 menunjukkan nilai probalitias sebesar $0,000<0,05$, maka $\mathrm{H}_{0}$ ditolak dan $\mathrm{H}_{1}$ diterima. Sehingga dapat disimpulkan bahwa terdapat peningkatan kemampuan penalaran matematika siswa kelas IV SD Negeri 239 Salu Minanga kecamatan Malili setelah penerapan model pembelajaran matematika berbasis masalah. Hal ini sejalan dengan penelitian Mikrayanti (2016) yang menyimpulkan bahwa ada peningkatan kemampuan penalaran matematis siswa melalui pendekatan pembelajaran berbasis masalah pada sekolah kategori baik, cukup dan kurang. Lebih lanjut hasil penelitian Herman (2007) menyimpulkan model pembelajaran berbasis masalah yang diterapkan cukup efektif dalam meningkatkan kemampuan penalaran siswa. Selain itu, respon siswa terhadap pembelajaran berbasis masalah secara umum cukup positif.

Peningkatan kemampuan penalaran siswa setelah pembelajaran matematika berbasis masalah dikarenakan dengan pembelajaran matematika berbasis masalah, siswa menjadi lebih aktif, siswa dilatih untuk menyelesaikan masalah sendiri, siswa di latih untuk menyampaikan pendapatnya sendiri, dan siswa di latih untuk mengevaluasi pendapatnya dan perdapat temantemannya . Sehingga pembelajaran bermakna bagi siswa. menurut Herman (2007) agar kemampuan penalaran siswa lebih berkembang, maka selama proses pembelajaran berlangsung diharapkan siswa terlibat secara aktif dalam melakukan aktivitas matematis, misalnya siswa melakukan diskusi dengan rekannya maupun dengan guru mengenai permasalahan matematika sehingga dapat mengkonstruksi dan mengevaluasi argumen-argumen mereka sendiri maupun argumen-argumen rekannya, serta dapat melakukan generalisasi saat penarikan kesimpulan.

Hasil uji hipotesis 2 sebagai berikut.

Tabel 9. Hasil uji hipotesis 2

\begin{tabular}{|c|c|c|c|c|c|c|c|c|}
\hline \multicolumn{9}{|c|}{ Paired Samples Test } \\
\hline & \multicolumn{5}{|c|}{ Paired Differences } & \multirow{3}{*}{$\mathrm{t}$} & \multirow{3}{*}{$\mathrm{df}$} & \multirow{3}{*}{$\begin{array}{l}\text { Sig. (2- } \\
\text { tailed) }\end{array}$} \\
\hline & \multirow[t]{2}{*}{ Mean } & \multirow[t]{2}{*}{$\begin{array}{c}\text { Std. } \\
\text { Deviati } \\
\text { on }\end{array}$} & \multirow[t]{2}{*}{$\begin{array}{l}\text { Std. Error } \\
\text { Mean }\end{array}$} & \multicolumn{2}{|c|}{$\begin{array}{l}\text { 95\% Confidence } \\
\text { Interval of the } \\
\text { Difference }\end{array}$} & & & \\
\hline & & & & Lower & Upper & & & \\
\hline $\begin{array}{l}\text { pretest } \\
\text { motivasi } \\
\text { - posttest } \\
\text { motivasi }\end{array}$ & $-20,52778$ & 9,63175 & 1,60529 & $-23,78669$ & $-17,26886$ & $-12,788$ & 35 &, 000 \\
\hline
\end{tabular}

Sumber: Data primer setelah di olah (2021)

Tabel 9 menunjukkan nilai probalitias sebesar $0,000<0,05$, maka $\mathrm{H}_{0}$ ditolak dan $\mathrm{H}_{1}$ diterima. Sehingga dapat disimpulkan bahwa terdapat perbedaan motivasi belajar matematika siswa kelas IV SD Negeri 239 Salu Minanga kecamatan Malili setelah penerapan pembelajaran matematika berbasis masalah. Perbedaan motivasi belajar siswa sebelum dan setelah penerapan pembelajaran matematika berbasis masalah dapat dilihat dari rata-ratanya. Rata-rata motivasi belajar siswa setelah penerapan pembelajaran matematika berbasis masalah lebih tinggi dari 
rata-rata motivasi belajar siswa sebelum penerapan pembelajaran matematika berbasis masalah. Ini menunjukkan bahwa ada peningkatan motivasi belajar siswa setelah diajar pembeajaran matematika berbasis masalah. Hal ini selajan dengan penelitian Periandani, \& Gita, (2019) yang menyimpulkan bahwa motivasi belajar matematika siswa Kelas VIII B SMPN 7 Singaraja dengan penerapan model pembelajaran berbasis masalah mengalami peningkatan. Lebih lanjut hasil penelitian Pradnyana, Marhaeni, \& Made, (2013) menyimpulkan terdapat perbedaan yang signifikan terhadap motivasi belajar dalam pembelajaran matematika siswa kelas IV SD Gugus I Kecamatan Buleleng antara siswa yang mengikuti pembelajaran berbasis masalah dan siswa yang mengikuti pembelajaran konvensional. Motivasi belajar siswa yang diajar dengan pembelajaran berbasis masalah lebih baik dibandingkan dengan motivasi belajar siswa yang diajar dengan pembelajaran konvensional.

Peningkatan moyivasi belajar ini di karenakan dengan pembelajaran berbasis masalah pembelajaran yang dilakukan berpusat pada siswa, siswa lebih terlibat aktif berdiskusi dengan kelompoknya dalam mencari solusi dari masalah yang di berikan, sehingga siswa lebih bersemangat mengikuti pembelajaran. Menurut Periandani, \& Gita, (2019) motivasi belajar siswa dapat meningkat dengan pembelajaran berbasis masalah karena di setiap kegiatan pembelajaran dengan model pembelajaran berbasis masalah mengajak siswa untuk fokus dan memusatkan perhatiannya dalam mengikuti proses pembelajaran. Selain itu, dengan penerapan model pembelajaran berbasis masalah dalam proses pembelajaran membuat siswa lebih antusias dalam belajar karena pada model ini siswa membangun pengetahuannya dengan diskusi kelompok, dan setiap kelompok dibimbing oleh guru serta dengan digunakannya permasalahan-permasalahan yang dekat dengan siswa membuat siswa lebih aktif dalam mengikuti kegiatan pembelajaran.

\section{F. Kesimpulan}

Berdasarkan hasil analisis dan pembahasan, di peroleh kesimpulan bahwa pembelajaran matematika berbasis masalah dapat meningkatkan kemampuan penalaran dan motivasi belajar siswa kelas IV SD negeri 239 Salu Minanga kecamatan Malili. Kesimpulan secara rinci sebagai berikut.

1. Kemampuan penalaran matematika siswa kelas IV SD negeri 239 Salu Minanga kecamatan Malili sebelum diajar dengan pembelajaran berbasis masalah memiliki nilai rata-rata sebesar 50,92 berada pada kategori rendah.

2. Kemampuan penalaran matematika siswa kelas IV SD negeri 239 Salu Minanga kecamatan Malili setelah diajar dengan pembelajaran berbasis masalah memiliki nilai rata-rata sebesar 79,81 berada pada kategori sedang

3. Motivasi belajar siswa kelas IV SD negeri 239 Salu Minanga kecamatan Malili sebelum diajar dengan pembelajaran berbasis masalah memiliki nilai rata-rata sebesar 80,42 berada pada kategori sedang.

4. Motivasi belajar siswa kelas IV SD negeri 239 Salu Minanga kecamatan Malili setelah diajar dengan pembelajaran berbasis masalah memiliki nilai rata-rata sebesar 100,89 berada pada kategori sangat tinggi.

5. Terdapat peningkatan kemampuan penalaran matematika siswa kelas IV SD Negeri 239 Salu Minanga kecamatan Malili setelah penerapan pembelajaran matematika berbasis masalah.

6. Terdapat peningkatan motivasi belajar siswa kelas IV SD Negeri 239 Salu Minanga kecamatan Malili setelah penerapan pembelajaran matematika berbasis masalah. 


\section{DAFTAR PUSTAKA}

Arends, R. I. (2008). Learning to Teach. Yogyakarta: Pustaka Pelajar.

Casnan, C., Mahpudin, A., \& Fuadi, E. F. W. (2017). Perancangan Permainan Interaktif “Geocaching” Sebagai Inovasi Baru Pembelajaran Matematika. Edusentris, 4(2), 99-105.

Depdiknas, (2006). Kurikulum Tingkat Satuan Pendidikan. Jakarta: Depdiknas

Herman, T. (2007). Pembelajaran Berbasis Masalah untuk Meningkatkan Kemampuan Penalaran Matematis Siswa SMP. Cakrawala Pendidikan, 1(1), 41-62

Ma'rufi, Pasandaran, R. F., \& Yogi, A. (2018). Pemahaman Konsep Geometri Mahasiswa Berdasarkan Gaya Kognitif Mahasiswa. Proximal Jurnal Penelitian Matematika dan Pendidikan Matematika 2(1), 56-67.

Mikrayanti, M. (2016). Meningkatkan kemampuan penalaran matematis melalui pembelajaran berbasis masalah. Suska Journal of Mathematics Education, 2(2), 97-102.

Mullis, I. V. S., Martin, M. O., Foy, P., \& Hooper, M. (2016). Appendix F: The Test-Curriculum Matching Analysis-Mathematics. In TIMSS 2015 International Results in Mathematics. Retrieved from http://timssandpirls.bc.edu/timss2015/internationalresults/timss-2015/mathematics/appendices.

Periandani, P. P., \& Gita, I. N. (2019). Penerapan Model Pembelajaran Berbasis Masalah Untuk Meningkatkan Motivasi Dan Prestasi Belajar Matematika Siswa Kelas Viii B Smp N 7 Singaraja. Jurnal Pendidikan dan Pembelajaran Matematika Indonesia, 8(2), 93-101.

Pradnyana, P. B., Marhaeni, A. A. I. N., \& Made, C. I. (2013). Pengaruh Pembelajaran Berbasis Masalah Terhadap Motivasi Belajar dan Prestasi Belajar Matematika Siswa kelas IV SD (Doctoral dissertation, Ganesha University of Education).

Sofyan, H., \& Komariah, K. (2016). Pembelajaran Problem Based Learning dalam Implementasi Kurikulum 2013 di SMK. Jurnal Pendidikan Vokasi, 6(3), 260-271.

Sumartini, T. S. (2015). Peningkatan kemampuan penalaran matematis siswa melalui pembelajaran berbasis masalah. Mosharafa: Jurnal Pendidikan Matematika, 4(1), 1-10.

Usniati, M. (2011). Meningkatkan Kemampuan Penalaran Matematika Melalui Pendekatan Pemecahan Masalah. Tangerang. UIN Syarif Hidayatulloh. 